\title{
KESTABILAN MODEL MATEMATIKA PENULARAN PENYAKIT GONORRHOEAE
}

\author{
A.P. Aditya1, R. Ratianingsih², dan J.W. Puspita ${ }^{3}$ \\ 1,2,3Program Studi Matematika Jurusan Matematika FMIPA Universitas Tadulako \\ Jalan Soekarno-Hatta Km. 09 Tondo, Palu 94118, Indonesia \\ 1ardianza006@gmail.com, 2ratianingsih@yahoo.com, 3juni.wpuspita@yahoo.com
}

\begin{abstract}
Gonorrhoeae is a sexually acute bacterial transmitted disease (STD) that caused by gram-negative diplococci, Neisseria gonorrhoeae. The initial symptomps of the disease is a discharge of pus from the urethra orifice eksternumafter copulated. This research studies a mathematical model that represent the disease spread that adapted from the SI models. The male population groups, is divided into male vulnerable subpopulations Susceptiible $\left(S_{L}\right)$, Infected $\left(I_{L}\right)$ and the female population group is divided into subpopulations of female vulnerable to $\left(S_{L}\right)$, Infected $\left(I_{P}\right)$. The model is represented into a system of nonlinear differential equations that describe the dynamics of each subpopulation groups with respect to the time changes. The model has two critical points. The first critical point represents a free-disease condition, while the second one represents an endemic of STD. The model is analyzed by determine the eigenvalues of Jacobian matrix that evaluated at the critical points. The results is both critical points are stable. This indicates that the free-disease and endemic conditions are persist. The simulations also shows that the male subpopulations are more rapidly infected comparing to the female because of the disease transmission of gonorrhoeae in female subpopulations is just infected from male subpopulation, while the transmitions in male subpopulation is infected from both subpopulation of female and male.
\end{abstract}

Keywords : Eigenvalues, Gonorrhoeae, Model SI, Routh Hurwitz, Stability Analysis.

\section{ABSTRAK}

Gonorrhoeae merupakan salah satu penyakit menular seksual (PMS) yang bersifat akut penyakit ini disebabkan oleh bakteri diplokokus gramnegatif, Neisseria gonorrhoeae. Gejala awal penyakit ini adalah keluarnya nanah dari orifisium uretra eksternum sesudah melakukan hubungan kelamin. Dalam penelitian ini, model matematika yang merepresentasikan penyebaran penyakit tersebut diadaptasi dari model SI. Kelompok populasi laki-laki dibagi atas subpopulasi laki-laki rentan Susceptiible $\left(S_{L}\right)$, Infected $\left(I_{L}\right)$, dan kelompok populasi perempuan dibagi atas subpopulasi perempuan rentan Susceptiible $\left(S_{P}\right)$, Infected $\left(I_{P}\right)$. Model yang diperoleh merupakan sistem persamaan diferensial tak linier yang menggambarkan dinamika setiap kelompok subpopulasi seiring dengan perubahan waktu. Dari model tersebut diperoleh dua titik kritis. Titik kritis pertama menggambarkan kondisi bebas penyakit, sedangkan titik kritis kedua menggambarkan kondisi endemik penyebaran penyakit menular seksual (PMS). Model yang dibangun selanjutnya dianalisis kestabilannya dengan cara menentukan nilai eigen dari matriks Jacobi yang dievaluasi pada kedua titik kritis. Hasil penelitian menunjukkan bahwa titik kritis bebas penyakit dan endemik adalah stabil. Hal ini menunjukkan bahwa kondisi bebas penyakit dan endemik bersifat menetap. Hasil simulasi memperlihatkan bahwa subpopulasi laki-laki lebih cepat tertular dibandingkan subpopulasi perempuan 
karena penularan penyakit gonorrhoeae pada subpopulasi perempuan terinfeksi hanya tertular dari subpopulasi laki-laki saja, sedangkan subpopulasi laki-laki yang terinfeksi tertular penyakit tersebut dari subpopulasi perempuan dan laki-laki (waria).

Kata kunci : Nilai Eigen, Gonorrhoeae, Model SI, Routh Hurwitz, Analisis Kestabilan.

\section{PENDAHULUAN}

Perkembangan zaman dan teknologi membawa perubahan, baik yang berdampak positif maupun negatif. Salah satu dampak negatifnya adalah pergeseran nilai-nilai budaya, seperti seks bebas dan berganti pasangan, yang mengakibatkan penularan penyakit menular seksual (PMS). Salah satu PMS yang bersifat akut adalah gonorrhoeae. Penyakit ini disebabkan oleh bakteri diplokokus gram negatif, Neisseria gonorrhoeae. Gejala awal penyakit ini adalah keluarnya nanah dari orifisium uretra eksternum sesudah melakukan hubungan kelamin.

Di Indonesia, infeksi gonorrhoeae menempati urutan tertinggi dari semua jenis PMS. Dalam Surveilans Terpadu Biologis dan Perilaku (STBP) prevalensi gonorrhoeae di Indonesia paling tinggi pada kelompok Wanita Pekerja Seks Langsung (WPSL) yakni sebesar 38\%, kemudian diikuti oleh waria (29\%), dan Wanita Pekerja Seks Tidak Langsung (WPSTL) (19\%) (Kandun, 2011). Di Kota-kota besar seperti Surabaya, Jakarta, dan Bandung menunjukkan tingginya gonorrhoeae mencapai 7,4\% - 50\% (Lina, 2011). Data yang diperoleh dari RSU Dr. Soetomo surabaya periode 2002-2006 jumlah orang yang terkena penyakit gonorrhoeae sebanyak 321 orang, dimana Laki-laki terkena penyakit sekitar $90,7 \%$ dan perempuan $9,3 \%$ (Jawas, 2008.).

Model matematika penularan penyakit gonorrhoeae pada populasi laki-laki,perempuan, dan waria akan dikonstruksi dalam penelitian ini. Waria mempunyai pengaruh yang besar terhadap penularan penyakit gonorrhoeae sehingga penulis memasukkan waria ke dalam model. Penularan pada populasi waria yang di maksud dalam model ini adalah laki-laki yang rentan berinteraksi seksual dengan laki-laki yang telah terinfeksi. Model matematika yangtelah dibentuk akan dianalisa kestabilannya untuk mengetahui perilaku jangka panjang penyebaran penyakit gonorrhoeae menggunakan metode linearisasi. Sebagai deskripsi dari fenomena penularan penyakit gonorrhoeae dilakukan simulasi untuk mendapatkan gam barankecocokan model yang dibangun dengan keadaan real di lapangan.

\section{METODE PENELITIAN}

Penelitian ini merupakan tinjauan matematis terhadap penanganan penularan penyakit gonorrhoeae pada manusia dengan model matematika melalui analisa ke stabilan di titik kritis sistem. Metode yang digunakan adalah metode linearisasi. Linearisasi adalah proseshampiran 
sistem persamaan diferensial tak linier dengan sistem persamaan diferensial linier yang ekivalen. Linearisasi digunakan untuk menyelesaikan sistem autonomous yang berbentuk

$\left.\begin{array}{l}\frac{d x}{d t}=f(x, y) \\ \frac{d y}{d t}=g(x, y)\end{array}\right\}$

dimana $f(x, y)$ dan $g(x, y)$ adalah persamaan tak linear. Jika $\left(x_{0}, y_{0}\right)$ merupakan titik kritis dari sistem persamaan ( 1 ), maka :

$f\left(x_{0}, y_{0}\right)=0$ dan $g\left(x_{0}, y_{0}\right)=0$

।

Kestabilan dari titik kritis dapat diamati melalui nilai eigen yang memenuhi $f(\lambda)=\operatorname{det}(\lambda I-J)=$ 0 , dimana $J=\left[\begin{array}{ll}f_{x}\left(x_{0}, y_{0}\right) & f_{y}\left(x_{0}, y_{0}\right) \\ g_{x}\left(x_{0}, y_{0}\right) & g_{y}\left(x_{0}, y_{0}\right)\end{array}\right]$ adalah matriks Jacobi yang dievaluasi dititik kritis $\left(x_{0}, y_{0}\right)$.

\subsection{Routh-Hurwitz}

Kriteria kestabilan Routh-Hurwitz adalah suatu metode yang mengkaji kestabilansistem dengan hanya mem perhatikan koefisien dari persamaan karateristik tanpa menghitung akar akar karateristik secara langsung (Subiono,2013). Diberikan suatu persamaan karateristik dengan orde ke-n sebagai berikut :

$f(\lambda)=a_{0} \lambda^{n}+a_{1} \lambda^{n-1}+a_{2} \lambda^{n-2}+\cdots+a_{n-1} \lambda+a_{n}=0$

Jika semua koefisien persamaan karateristik positif, dan semua suku pada kolom pertamatabel (1) bertanda positif, maka semua akar karateristik dari persamaan ( 2 ) adalah negatif.

Tabel 1 : Kriteria Routh-Hurwitz

\begin{tabular}{|cccc|}
\hline$\lambda^{n}$ & $a_{n}$ & $a_{n-2}$ & $a_{n-4}$ \\
$\lambda^{n-1}$ & $a_{n-1}$ & $a_{n-3}$ & $a_{n-5}$ \\
$\lambda^{n-2}$ & $b_{1}$ & $b_{2}$ & $b_{3}$ \\
$\lambda^{n-3}$ & $c_{1}$ & $c_{2}$ & $c_{3}$ \\
$\lambda^{n-3}$ & $d_{1}$ & $d_{2}$ & $d_{3}$ \\
$\vdots$ & $\vdots$ & $\vdots$ & $\vdots$ \\
$\lambda^{2}$ & $e_{1}$ & $e_{2}$ & \\
$\lambda$ & $f_{1}$ & & \\
$\lambda^{0}$ & $g_{1}$ & & \\
& & & \\
\hline
\end{tabular}


Nilai $b_{1}, b_{2}, b_{3}, c_{1}, c_{2}$ dan $c_{3}$ pada tabel 1 diperoleh dari perhitungan berikut ini :

$$
\begin{array}{cc}
b_{1}=\frac{a_{n-1} a_{n-2}-a_{0} a_{n-3}}{a_{n-1}} & c_{1}=\frac{b_{1} a_{n-3}-a_{n-1} b_{2}}{b_{1}} \\
b_{2}=\frac{a_{n-1} a_{n-4}-a_{n} a_{n-5}}{a_{n-1}} & c_{2}=\frac{b_{1} a_{n-5}-a_{n-1} b_{3}}{b_{1}} \\
\vdots & \\
\vdots \\
b_{n}=\frac{a_{1} a_{2 n}-a_{0} a_{2 n+1}}{a_{1}} & c_{n}=\frac{b_{1} a_{2 n+1}-a_{1} b_{n+1}}{b_{1}}
\end{array}
$$

\subsection{Aturan Descartes}

Misalkan $f(\lambda)$ adalah polinomial atas variable $\lambda$ dengan koefisien real dan kostantatidak nol, maka banyaknya akar-akar persamaan yang mungkin dapat dicari dengan descartes'rule of sign, yaitu

- $\quad$ Banyaknya akar penyeleseian positif dari persamaan $f(\lambda)=0$ sama atau kurang dari jumlah variasi (perubahan) pada tanda koefisien $f(\lambda)$.

- $\quad$ Banyaknya akar penyeleseian negatif dari persamaan $f(\lambda)=0$ sama atau kurang dari jumlah variasi (perubahan) tanda pada koefisien $f(-\lambda)$.

Perubahan tanda pada polinomial ini dapat dilihat dari tanda positif ke tanda negatif atau sebaliknya. ( Drucker, D.S. 1979).

\section{HASIL DAN PEMBAHASAN}

\subsection{Model Matematika Penularan Penyakit Gonorrhoeae Pada Manusia}

Penelitian ini mengasumsikan infeksi penyakit gonorrhoeae terjadi karena kontak seksual antara laki-laki yang terinfeksi dengan perempuan yang sehat, dan kontak seksual antara perempuan yang terinfeksi dengan laki-laki yang sehat dengan laju infeksi yang sama. Selain itu, infeksi juga bisa terjadi karena kontak seksual antara laki-laki yang rentan dengan laki-laki yang terinfeksi (waria). Akibatnya, populasi manusia dibagi menjadi 4 subpopulasiyaitu subpopulasi laki-laki rentan $\left(S_{L}\right)$, subpopulasi perempuan rentan $\left(S_{P}\right)$, subpopulasi laki-laki terinfeksi $\left(I_{L}\right)$, dan subpopulasi perem puan terinfeksi $\left(I_{P}\right)$. Populasi manusia dianggapkonstan. Adapun diagram kompartemen penyebaran penyakit gonore yang disebabkan oleh bakteri diplokokus gram negatif, Neisseria gonorrhoeae dapat dilihat pada Gambar 1, dimanadeskripsi parameter yang terlibat dalam model dapat dilihat pada tabel 2. Kematian akibatinfeksi tidak dilibatkan dalam model dikarenakan peluang kematian sangat kecil. 


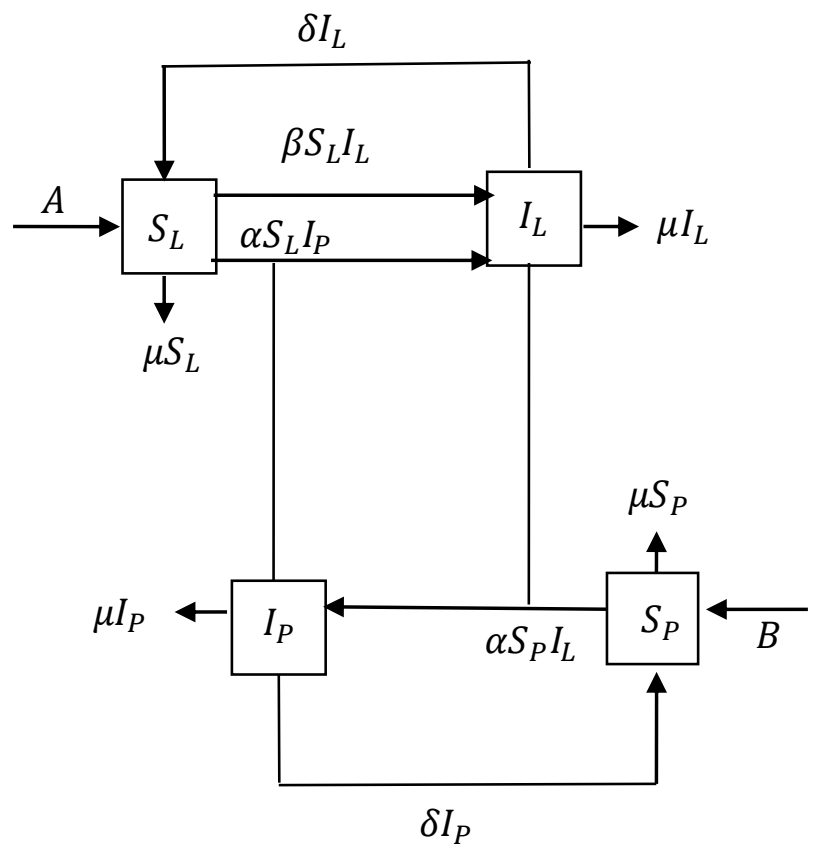

Gambar 1 : Diagram Kompartemen Penularan Penyakit Gonorrhoeae

Tabel 2 : Deskripsi dan Nilai Parameter

\begin{tabular}{|c|l|c|c|}
\hline Parameter & \multicolumn{1}{|c|}{ Deskripsi } & Nilai & Keterangan \\
\hline A & $\begin{array}{l}\text { Tingkat rekrutmen } \\
\text { populasi laki-laki }\end{array}$ & 0,08385753 & $\frac{5 \text { tahun rata - rata jumlah populasi }}{365 \times 5 \text { tahun }}$ \\
\hline B & $\begin{array}{l}\text { Tingkat rekrutmen } \\
\text { populasi perempuan }\end{array}$ & 0,08385753 & $\frac{5 \text { tahun rata }- \text { rata jumlah populasi }}{365 \times 5 \text { tahun }}$ \\
\hline$\mu$ & Kematian alami & 0,0000421 & $\frac{1}{\text { life time }}$ \\
\hline$\beta$ & Laju infeksi waria & $(0,1)$ & Asumsi \\
\hline$\alpha$ & Laju penularan & $(0,1)$ & Asumsi \\
\hline$\delta$ & Laju pemulihan & 0,0357143 & $\frac{1}{\text { waktu infeksi }+ \text { waktu pemulihan }}$ \\
\hline
\end{tabular}


Dari diagram kompartemen pada Gambar 1 dibangun model matematika penularan penyakit gonorrhoeae, yang dapat dituliskan ke dalam sistem persamaan diferensial (SPD) sebagai berikut :

$$
\left.\begin{array}{rl}
\frac{d S_{L}}{d t} & =A+\delta I_{L}-\alpha S_{L} I_{P}-\beta S_{L} I_{L}-\mu S_{L} \\
\frac{d S_{L}}{d t} & =B+\delta I_{P}-\alpha S_{P} I_{L}-\mu S_{P} \\
\frac{d S_{L}}{d t} & =\alpha S_{L} I_{P}+\beta S_{L} I_{L}-\mu I_{L}-\delta I_{L} \\
\frac{d S_{L}}{d t} & =\alpha S_{P} I_{L}-\mu I_{P}-\delta I_{P}
\end{array}\right\}
$$

\subsection{Analisis Kestabilan dari Model}

\subsubsection{Titik Kritis dan Eksistensinya}

Titik kritis dari sistem persamaan (3) diperoleh dengan menyelesaikan persamaan-persamaan sebagai berikut :

$$
\frac{d S_{L}}{d t}=0, \frac{d S_{P}}{d t}=0, \frac{d I_{L}}{d t}=0, \frac{d I_{P}}{d t}=0
$$

Sehingga diperoleh 2 titik kritis, yaitu $T_{1}=\left(\frac{A}{\mu}, \frac{B}{\mu}, 0,0\right)$ dan $T_{2}=$ $\left(\frac{\mu\left(2 \mu \theta+\theta^{2}+\mu^{2}\right)}{\alpha^{2}\left(B-\mu I_{P}\right)+\beta \mu^{2}+\beta \theta \mu}, \frac{B-\mu I_{P}}{\mu}, \frac{\mu I_{P}(\mu+\delta)}{\alpha\left(B-\mu I_{P}\right)}, I_{P^{*}}\right)$, dengan $I_{P}$ memenuhi polinomial berikut ini:

$P\left(I_{P}\right)=a_{2} I_{P}^{2}+a_{1} I_{P}+a_{0}=0$

dimana :

$$
\begin{aligned}
a_{2}= & \alpha^{2} \mu^{4}+A \alpha^{3} \mu^{2}+\mu^{3} \theta \alpha^{2} \\
a_{1}= & \alpha \mu^{5}-A \alpha \mu^{3} \beta-\mu^{3} \theta^{2} \beta-\alpha^{2} \mu^{3} B-2 \mu^{4} \theta \beta+2 \alpha \mu^{4} \theta+\alpha \mu^{3} \theta^{2}-2 A \alpha^{3} B \mu-\beta \mu^{5} \\
& -\mu^{2} \theta \alpha^{2} B-A \alpha \mu^{2} \beta \theta \\
a_{0}= & A \alpha^{3} \beta^{2}+A \alpha B \beta \mu^{2}-\mu^{2} \alpha B \theta^{2}-\mu^{4} \alpha B+A \alpha B \beta \theta \mu-2 \mu^{3} \alpha B \beta
\end{aligned}
$$

akar-akar $I_{P}{ }^{*}$ dari polinomial diatas sulit untuk ditunjukkan secara eksplisit. Namun, eksistensinya dapat dijamin dengan menggunakan aturan descartes. Titik kritis $T_{1}$ menggambarkan kondisi bebas penyakit, sedangkan titik kritis $T_{2}$ menggambarkan kondisi endemik.

Titik kritis pertama dapat dijamin eksistensinya karena $S_{L}=\frac{A}{\mu}$ dan $S_{P}=\frac{B}{\mu}$ bernilai non negatif. Sedangkan eksistensi titik kritis endemik penyakit gonorrhoeae $T_{2}$ akan tercapai jika $I_{P}{ }^{*}>0$ dan $B>\mu I_{P}$. Nilai $I_{P}{ }^{*}>0$ dapat dijamin jika $A \alpha \beta>(\alpha-\beta)\left(\mu^{2}+\right.$ $\delta \mu)$. 


\subsubsection{Kestabilan dari Titik Kritis}

Kestabilan dari Titik kritis $T_{1}$ dan $T_{2}$ dapat ditentukan melalui tanda negatif dari semua nilai eigen $\lambda$ yang diperoleh dari matriks Jacobi. Matriks Jacobi dari sistem persamaan diferensial ( 3 ) yang dievaluasi pada $T_{1}$ memberikan persamaan karateristik dalam $\lambda$ sebagai berikut :

$(\lambda+\mu)^{2}\left(\mu^{2} \lambda^{2}+\left(2 \mu^{2} \delta-\beta A \mu+2 \mu^{3}\right) \lambda-\beta A \mu^{2}-\mu \beta A \delta+\mu^{4}+2 \mu^{3} \delta+\mu^{2} \delta^{2}+\alpha^{2} B A\right)$

Dari suku pertama persamaan (3.6) diperoleh nilai eigen, $\lambda_{1,2}=-\mu$, sehingga kestabilan sistem ditentukan oleh persamaan berderajat 2 dalam $\lambda$ sebagai berikut :

$a_{2} \lambda^{2}+a_{1} \lambda+a_{0}=0$

dimana:

$a_{2}=\mu^{2}>0$

$a_{1}=\mu(2 \mu(\mu+\delta)-\beta A)$

$a_{0}=-\beta A \mu^{2}-\beta A \delta \mu+\mu^{4}+2 \mu^{3} \delta+\mu^{2} \delta^{2}+\alpha^{2} B A$

Berdasarkan metode Routh-Hurwitz, kestabilan dari titik kritis $T_{1}$ dapat dijamin jika $a_{0}>$ 0 dan $a_{1}>0$. Akibatnya diperoleh syarat kestabilan dari $T_{1}$ sebagai berikut :

$A>\frac{2 \mu^{2}(\delta+\mu)}{\beta \mu}$ dan $A>\frac{\mu^{2}\left(\mu^{2}+2 \mu \delta+\delta^{2}\right)}{\beta \mu(\mu+\delta)+\alpha^{2} B}$

Matriks Jacobi dari sistem persamaan differensial (SPD) yang dievaluasi pada $T_{2}$ memberikan persamaan karateristik dalam $\lambda$ sebagai berikut :

$(\lambda+\mu)(\lambda+\mu)\left(a_{2} \lambda^{2}+a_{1} \lambda+a_{0}\right)=0$

dimana :

$$
\begin{aligned}
a_{2}= & \alpha\left(B-\mu I_{P}\right)^{2}\left(\alpha^{2}\left(B-\mu I_{P}\right)+\beta \mu(\delta+\mu)\right) \\
a_{1}= & \left(B-\mu I_{P}\right)\left(2 B^{2} \alpha^{3} \mu+2 B^{2} \alpha^{3} \delta+B^{2} I_{P} \alpha^{4}-2 B I_{P}{ }^{2} \alpha^{4} \mu-3 B I_{P} \alpha^{3} \mu^{2}+B \alpha \beta \mu^{3}+B \alpha \beta \delta^{2} \mu\right. \\
& +2 B \alpha \beta \delta \mu^{2}+2 B I_{P} \alpha^{2} \beta \mu^{2}+2 B I_{P} \alpha^{2} \beta \delta \mu-3 B I_{P} \alpha^{3} \delta \mu+I_{P}{ }^{2} \alpha^{3} \delta \mu^{2}-2 I_{P}{ }^{2} \alpha^{2} \beta \mu^{3} \\
& \left.+I_{P}{ }^{3} \alpha^{4} \mu^{2}+I_{P} \beta^{2} \mu^{4}+2 I_{P} \beta^{2} \delta \mu^{3}+I_{P} \beta^{2} \delta^{2} \mu^{2}-2 I_{P}{ }^{2} \alpha^{2} \beta \delta \mu^{2}+I_{P}{ }^{2} \alpha^{3} \mu^{2}\right) \\
a_{0}= & I_{P}(\mu+\delta)\left(\mu^{4} I_{P}{ }^{2} \alpha^{3}+\mu^{4} \beta^{2} B-2 \mu^{3} B I_{P} \alpha^{2} \beta+2 \mu^{3} B \beta^{2} \delta+\mu^{3} I_{P}{ }^{2} \alpha^{3} \delta-2 \mu^{3} I_{P} B \alpha^{3}\right. \\
& -2 \mu^{2} I_{P} B \alpha^{2} \beta \delta+B^{3} \alpha^{4}+\mu^{2} I_{P}{ }^{2} B \alpha^{4}+2 \mu^{2} B^{2} \alpha^{2} \beta-2 \mu^{2} I_{P} B \alpha^{3} \delta+\mu^{2} B^{2} \alpha^{3}+\mu^{2} B \beta^{2} \delta^{2} \\
& \left.-2 \mu B^{2} I_{P} \alpha^{4}+\mu B^{2} \alpha^{3} \delta+2 \mu B^{2} \alpha^{2} \beta \delta\right)
\end{aligned}
$$


Dari suku pertama persamaan ( 6 ) diperoleh nilai eigen, $\lambda_{1,2}=-\mu$, sehingga kestabilan sistem ditentukan oleh persamaan berderajat 2 dalam $\lambda$ sebagai berikut

$a_{2} \lambda^{2}+a_{1} \lambda+a_{0}=0$

Berdasarkan metode Routh-Hurwitz, kestabilan dari titik kritis $T_{2}$ dapat dijamin jika $a_{0}>$ 0 dan $a_{1}>0$. Akibatnya diperoleh syarat kestabilan dari $T_{2}$ sebagai berikut :

$$
\begin{aligned}
& I_{P} \beta^{2} \mu^{4}+\left(\beta \alpha B+2 I_{P} \beta^{2} \delta+I_{P}^{2} \alpha^{3}\right) \mu^{3}+\left(2 B \beta \alpha \delta+2 B I_{P} \alpha^{2} \beta+I_{P}{ }^{2} \alpha^{3} \delta I_{P}^{3} \alpha^{4}+I_{P} \beta^{2} \delta^{2}\right) \mu^{2} \\
& +2 B \alpha\left(\beta \alpha B+2 I_{P} \beta^{2} \delta+\frac{1}{2} \beta \delta^{2}\right) \mu+B^{2} \alpha^{3}\left(I_{P} \alpha+2 \delta\right)>2\left(B I_{P} \alpha^{2}+\frac{3}{2} B(\mu+\delta) \alpha\right. \\
& \left.+I_{P} \mu \beta(\mu+\beta)\right) I_{P} \alpha^{2} \mu
\end{aligned}
$$

dan

$$
\begin{aligned}
& \left(I_{P}{ }^{2} \alpha^{3}+\beta^{2} B\right) \mu^{4}+\left(I_{P}{ }^{2} \alpha^{3} \delta+2 B \beta^{2} \delta\right) \mu^{3}+2 B\left(\alpha^{2}\left(\frac{1}{2} \alpha+\beta\right) B+\frac{1}{2} \delta^{2} \beta^{3} \frac{1}{2} \delta^{2} \beta^{2}\right. \\
& \left.+\frac{1}{2} \alpha^{4} I_{P}{ }^{2}\right) \mu^{2}+2 \delta B^{2} \alpha^{2}\left(\frac{1}{2} \alpha+\beta\right) \mu+B^{3} \alpha^{4}>2 B \alpha^{2} I_{P}\left(\left(\mu^{2}+\mu \delta\right)(\beta+\alpha)+B \alpha^{2}\right) \mu
\end{aligned}
$$

\subsection{Simulasi}

Simulasi penyebaran penyakit gonorrhoeae dilakukan untuk nilai-nilai parameter yang ditentukan berdasarkan analisis endemik dari model penyakit gonorrhoeae yangmemunculkan syarat eksistensi dan syarat kestabilan untuk suatu titik kritis. Kita dapat melakukan simulasi dengan mengunakan nilai variabel dan nilai parameter, dimana $S_{L}$ adalah jum lah populasilakilaki yang rentan, $S_{P}$ adalah jum lah populasi perempuan yang rentan, $I_{L}$ adalah jum lah populasi laki-laki yang terinfeksi dan $I_{P}$ adalah jum lah perempuan yang terinfeksi. Dari nilai parameter dan nilai variable kita dapatkan simulasi seperti dibawah ini :

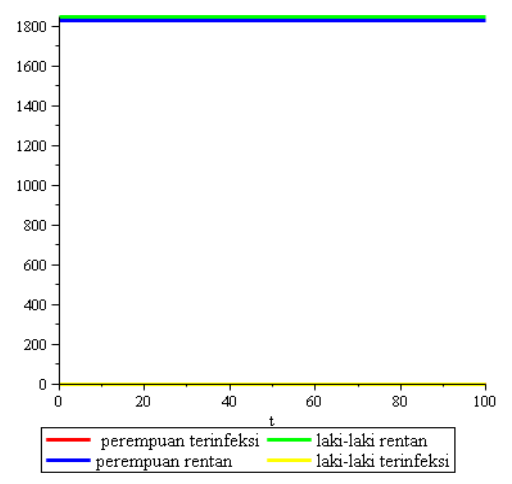

(a)

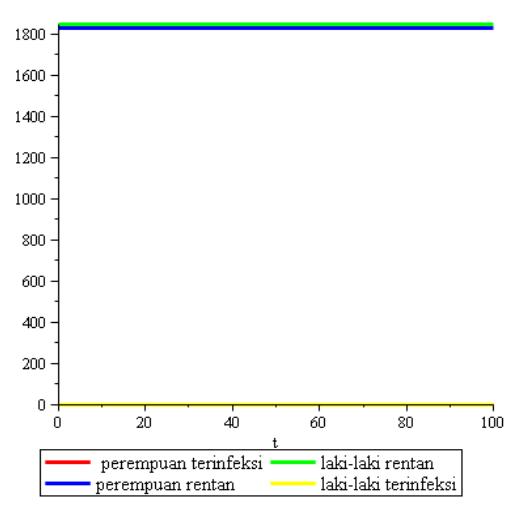

(b) 
Gambar 2 : Kurva Simulasi Kondisi Bebas Penyakit. (a) Nilai parameter $\beta=0.0001$ dan $\alpha=$ 0.0002; (b) Nilai parameter $\beta=0.001$ dan $\alpha=0.002$,

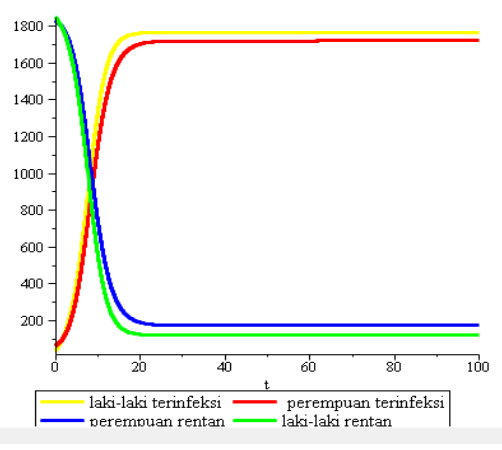

(a)

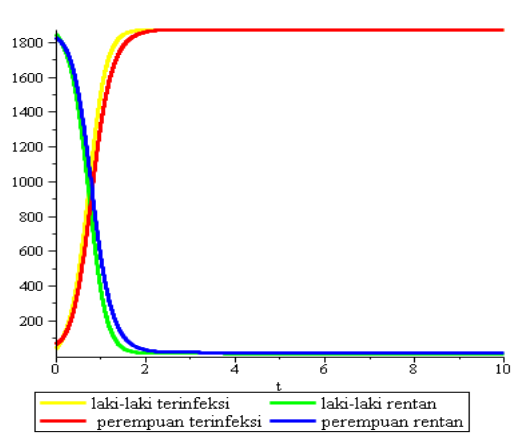

(b)

Gambar 3 : Kurva Simulasi Kondisi Endemik Penyakit gonorrhoeae. (a) Nilai parameter $\beta=$ 0.0001 dan $\alpha=0.0002$; (b) Nilai parameter $\beta=0.001$ dan $\alpha=0.002$,

Gambar 2 menggambarkan keadaan populasi bebas penyakit. Simulasi untuk titik kritis bebas penyakit ini dilakukan dengan menggunakan nilai awal $S_{P}(0)=1829, S_{L}(0)=1851, I_{P}(0)=0$, $I_{L}(0)=0$, dengan nilai parameter $\alpha$ dan $\beta$ ditentukan berdasarkan syarat eksistensi dan syarat kestabilan. Gambar 2 menunjukkan populasi yang konstan dalam waktu seratus hari tanpa adanya penyakit gonorrhoeae. Sedangkan Gambar 3 menggambarkan dinamika keadaan populasi endemik. Simulasi untuk titik kritis endemik penyakit gonorrhoeae ini diperolehdengan menggunakan nilai awal $S_{P}(0)=1829, S_{L}(0)=1851, I_{P}(0)=65, I_{L}(0)=37$ dan parameter $\alpha$ dan $\beta$ ditentukan berdasarkan syarat eksistensi dan syarat kestabilan. Dari Gambar 3 terlihat bahwa subpopulasi laki-laki lebih cepat tertular dibandingkan subpopulasi perempuan. Hal ini ditunjukkan dengan jum lah subpopulasi laki-laki yang terinfeksi lebih tinggi jika dibandingkan dengan jumlah subpopulasi perem puan di waktu yang sama. Kondisi ini disebabkan oleh laju penularan penyakit subpopulasi perem puan yang terinfeksi hanya tertular dari subpopulasilakilaki saja sedangkan subpopulasi laki-laki yang terinfeksi tertular penyakit tersebut dari perempuan dan laki-laki (waria). Jumlah sub populasi laki-laki dan perempuan rentan akan menurun seiring meningkatnya jumlah manusia yang terinfeksi pada subpopulasi laki-laki maupun perempuan, dikarenakan laju infeksi kurang dari laju pemulihan sehingga jumlah populasi yang rentan akan berkurang seiring dengan pertambahan waktu dan konstan pada titik tertentu. 


\section{KESIMPULAN}

Penelitian ini telah menawarkan pendekatan model matematika untuk mengetahui perilaku jangka panjang fenomena penularan penyakit gonorrhoeae pada populasi manusia. Dari model matematika penularan penyakit gonorrhoeae diperoleh 2 titik kritis, yaitu titik kritis yang menggambarkan kondisi bebas penyakit dan titik kritis yang menggambarkan kondisi endemik. Eksistensi dan kestabilan dari titik kritis $T_{1}$ dan $T_{2}$ dapat dijamin dalam penelitian ini. Dari hasil simulasi menunjukkan bahwa subpopulasi laki-laki lebih cepat tertular dibandingkan subpopulasi perempuan karena penularan penyakit gonorrhoeae pada subpopulasi perempuan terinfeksi hanya tertular dari subpopulasi laki-laki saja sedangkan subpopulasilakilaki yang terinfeksi tertular penyakit tersebut dari subpopulasi perempuan dan laki-laki (waria).

\section{DAFTAR PUSTAKA}

[1] Chandranita, I., A, Manuaba, IImu Kebidanan Kesehatan Reproduksi Untuk Pendidikan bidan Ed.2. EGC, 2011, Jakarta.

[2] Drucker, D.S. (1979). A Second Look at Descartes' Rule of Signs : Mathematics Magazine, 1979, V. 52. No. 5 (sept). p. 237-238.

[3] Kandun, Surveilans Terpadu Biologis dan Perilaku(STBP) 2011 Prevalensi Gonore di Negara Indonesia, 2011, Jakarta.

[4] Kermack, W., MC Kendrick, A.G, A Contribution to the Mathematical Theory of Epidemics. Royal Society, 1927, 115: 700-721.

[5] Mamyer, J, Concepts of Mathematical Modeling. Mcgrow-hill book company, 1985, New York.

[6] Subiono. Sistem linear dan Kontrol Optimal. Institut Teknologi Sepuluh Nopember,2013, Surabaya. 